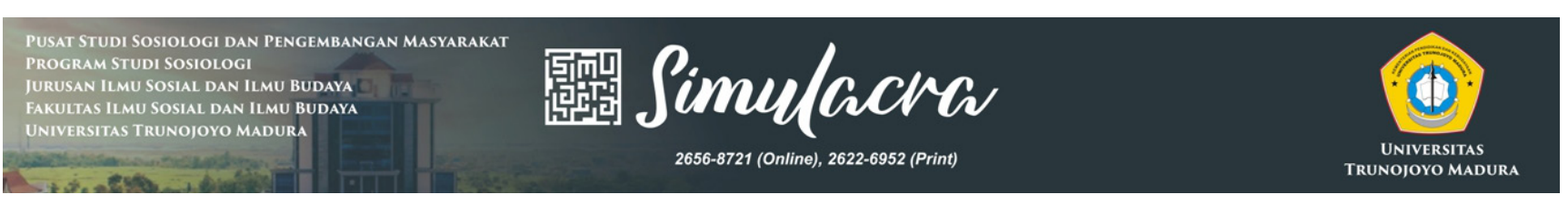

Volume 3, Issue 1, June 2020

Page 57-68

\title{
Ecotourism development based on local community empowerment: A case study in the forest village community institution of Wana Cendana, Dago Village, Bogor Regency
}

\author{
Ligar Abdillah ${ }^{1 *}$, Dody Prayogo ${ }^{2}$ \\ ${ }^{1 \& 2}$ Department of Sociology, Universitas Indonesia, Indonesia \\ ${ }^{*}$ Corresponding author \\ E-mail address: ligarsosiologi@gmail.com \\ DOI: https://doi.org/10.21107/sml.v3i1.7218
}

\begin{tabular}{l} 
ArtiCLE I N F O \\
\hline Keywords: \\
Ecotourism \\
Empowerment \\
Local community \\
Forest conservation
\end{tabular}

\begin{abstract}
A bstract
Forest Village Community Institutions (Lembaga Masyarakat Desa Hutan) generally use forest in the agriculture sector in accordance with instructions and capital support from Perhutani. LMDH Wana Cendana operates in the ecotourism sector without instructions and capital assistance from Perhutani. This study aims to analyze the implementation of empowering local communities (LMDH Wana Cendana) who do not have expertise in the field of forest management and ecotourism. The concept used is the empowerment of local communities and ecotourism with qualitative case study methods, thus promoting the novelty of cases and in-depth interviews with informants who are directly involved in the development of Gunung Dago ecotourism. Some previous research shows that empowerment does not prioritize local communities. The development of ecotourism in Dago Village, which began in 2019, prioritizes local potential and independent learning processes, so that local communities are able to transform exmining land into beautiful tourist attractions. The independence of the local community is reflected in its involvement in the ecotourism development process, from planning to implementation. In addition, local communities as managers are able to utilize local knowledge, culture and resources to improve the welfare of members without overruling the rules of forest conservation.
\end{abstract}

\section{Citation suggestion:}

Abdillah, L., \& Prayogo, D. (2020). Ecotourism development based on local community empowerment: A case study in the forest village community institution of Wana Cendana, Dago Village, Bogor Regency. Simulacra, 3(1), 57-68. https://doi.org/10.21107/sml.v3i1.7218

Received 9 May 2020; Received in revised form 28 May 2020; Accepted 2 June 2020; Published online 25 June 2020. 


\section{Introduction}

This article discussed community involvement in forestry activities that were motivated by an increase in forest destruction. The conversation of forest destruction on a global level revealed that population growth and expansion of agricultural and livestock land are the leading causes of increasing forest damage in the world (Ellis, Romero Montero, \& Hernández Gómez, 2017: 1). Forest destruction is a global challenge that must be addressed, both by governments, companies, organizations and communities to minimize and prevent deforestation (Brown \& Zarin, 2013: 805).

Community involvement in forestry activities is one of the factors that must be considered to strengthen the function of forests and improve the welfare of people in the forest area. Forest management will be useful when it involves communities supported by their social ties (Schelhas et al., 2016: 27). This step is beneficial to improve the welfare of the community while supporting the function of protecting forests. Such an effort is one form of handling forest problems that can be overcome by people around the forest who have experience and local wisdom (Kelly, 2018: 164).

Community participation in forest management is expected to be a driving force in regional development that can increase community income, employment, and environmental services (Ridwan, Junus, Mahbub, \& Windarti, 2018: 231). The approach that prioritizes the community is essential to create collaboration between the government and the community and find new opportunities in forestry activities (Timko, Green, Sharples, \& Grinde, 2015: 2). Equally important is the community's learning process in managing forests for social, economic, environmental, and cultural benefits (Hegde, Elias, Lamers, \& Hegde, 2017: 67).
Forest villages are villages that border directly with forests whose lives depend on the forest. Therefore, Perhutani as the authority in the management of stateowned forests, involves the community in the use and management of forests to realize independent farmers in accordance with the main objectives of the community development program village around the forest. In the program, Perhutani delegates arable land to the forest village, followed by the formation of the Forest Village Community Institute (LMDH) (Perhutani, 2019).

LMDH Wana Cendana is one of the parties cooperating with Perhutani in implementing forest utilization and management. The institute is located in Dago Village, Parungpanjang District, Bogor Regency, West Java Province. Local communities did not choose the agricultural sector as a medium of cooperation with Perhutani. Instead, they chose the ecotourism sector as a means of empowering members; it prioritized local potential independently and without instructions from Perhutani.

Some of the results of previous studies on ecotourism indicated that these activities tend to damage the environment and only promote tourists' interests (Stronza, Hunt, \& Fitzgerald, 2019: 234). The phenomenon at the research location showed the success of the local community (LMDH Wana Cendana) that succeeded in turning the former mining hill into a tourist spot. The hill was once exploited by Perhutani and a private company. Currently, it is managed by a local community that has absolutely no expertise in the field of forestry and ecotourism.

The results of previous studies showed that studies by Lowson and Kearns on empowerment in the UK for seven years have not achieved goals that prioritize the interests of society; instead it only prioritizes stakeholders (Lawson \& Kearns, 2014: 78). 
The second research result stated that the empowerment of local communities in the ecotourism sector developed in South Africa tended not to improve welfare because it did not involve local communities in program planning and implementation (Zanamwe, Gandiwa, Muboko, Kupika, \& Mukamuri, 2018: 10). These studies could be used as a basis for reviewing the involvement and welfare of local communities in the process of developing ecotourism.

Implementation of local communitybased empowerment needs to be researched, because empowerment, in general, does not emphasize the insights or habits of the empowered local people. This research focused on LMDH Wana Cendana activities that utilize village lap forests as tourist destinations. Thus, this research is fundamental, considering that LMDH Wana Cendana is a party in direct contact with the forest, uses the forest as a tourist destination, and is fully responsible for its sustainability.

This research aimed to explore the local potentials used by LMDH Wana Cendana in forest utilization in the ecotourism sector. Therefore, this study can complement previous studies that show the failure of empowering local communities. In addition, this study complements previous research on the failure of ecotourism that damages the environment. This research sought to enrich the findings that illustrate LMDH Wana Cendana's commitment and contribution to the development of ecotourism that prioritizes forest conservation.

\section{Method}

The application of qualitative methods in this study aimed to find various findings of the procedures for developing ecotourism that prioritizes the potentials of local communities in the Wana Cendana LMDH, Dago Village, Parung Panjang District, Bogor Regency. According to qualitative rules, this research not only described the surface findings, but it was possible to describe the involvement of local communities in the development of ecotourism in detail. The data collection was done by in-depth interviews, observation, and use of supporting documents (Mukhtar, 2013: 11).

The development of local communitybased ecotourism in Mount Dago is one form of contemporary phenomena. Ecotourism development activities in the area are considerably new for members of the local community who are members of the LMDH Wana Cendana. The Mount Dago Ecotourism was formalized in January 2019. The novelty of the case is very much in accordance with the provisions of case studies that focus on contemporary phenomena (Yin, 2008: 1).

Research related to the development of ecotourism based on local community empowerment is a type of case study research. This is caused by the focus of research that leads to a case or event. So, this study aimed to explore the case in the form of ecotourism development based on the empowerment of local communities in Dago Village. Thus, this research is very focused on the process of implementing ecotourism development in these locations, so case studies by Robert K. Yin is the most appropriate method(2008).

Research informants were those who have a variety of information related to the focus of this research. In this context, the key informant was those who has much knowledge about ecotourism development activities that prioritizes economic potential and were directly involved in these activities, from planning to implementation. The consideration regarding the informant adjusted to the rules of determining information in qualitative research which assumed that the informants understood the object of research information, both as an actor and others (Bungin, 2010: 76).

In qualitative case study research that prioritizes findings in the field, the techniques 
for determining informants must be adjusted to the research needs. The primary need for this research was detailed information regarding the implementation of local community-based ecotourism development (LMDH Wana Cendana). In this context, the researcher was not familiar with the location of the study. Therefore, the technique for determining the informant used snowball technique. The first step that must be done was to look for key informants. In general, key informants are leaders of an institution, community leaders, or people who are considered to understand the situation and conditions of research better (Mukhtar, 2013: 95).

Relevant to thesnowball technique, then the key informants should be LMDH chairman. In this context, the LMDH Chairperson has fulfilled several requirements: directly involved and had better understanding of the implementation of empowerment in the form of conservation and forest utilization activities for ecotourism. Researchers positioned key informants as those who genuinely understand the empowerment activities of local communities that utilize forests as tourist destination land. In this context, researchers did not know the parties involved in these activities. So, researchers relied heavily on information from key informants as consideration for determining supporting informants.

The key informant, the LMDH chairperson, fully understood the whole process of developing ecotourism and directly participated in it. Besides, the key informant also knew several members (supporting informants) who participated directly and understood the process of developing ecotourism from planning to implementation. To enrich the findings and information, it was necessary to conduct interviews with external parties concerned with the development of ecotourism, such as visitors, village government representatives and Perhutani Parung Panjang.

All information related to the development of ecotourism was related to the concept of Jim Ife and Frank Tesoriero which stated that the essential thing in empowering local community-based is to value knowledge, respect local culture, and value local resources (Ife \& Tesoriero, 2008: 242). In addition, the results of this study also needed to be linked to the concept of ecotourism according to The International Ecotourism Society (TIES) which defined ecotourism as a journey that has a responsibility to the environment (conservation), maintaining the welfare of the local community and inserting education in it (Uzama \& Walter, 2018: 26). Ecotourism is an alternative or a shortcut to sustainable development that promotes empowerment, economic, social, and environmental (Amalu, Otop, Duluora, Omeje, \& Emeana, 2018: 1259).

The emergence of the two concepts above is a form of criticism of the top-down empowerment model so that it prioritizes the empowerment program with a bottom-up model. The empowerment model of the two concepts is expected to be able to meet the needs of the empowered local community (Sardjo, Darmajanti, \& Boediono, 2017:1). The purpose of empowerment will be achieved by promoting community participation, open access, and capacity development (Ahmad \& Abu Talib, 2016: 1041).

The findings in the field were analyzed based on essential aspects found in the concept of empowering local communities and ecotourism. Important aspects contained in the two concepts are local knowledge, local culture, local community welfare and forest conservation efforts. In this context, researchers sought to enrich information regarding these four issues, both in-depth interviews, observation and the use of relevant supporting documents, such as 
village profiles, LMDH profiles, agreement letters between LMDH and Perhutani.

\section{Results and Discussion}

\section{LMDH Overview of Wana Cendana and Gunung Dago Ecotourism}

LMDH Wana Cendana, which consists of 42 members, is currently utilizing the village production forest of nearly $20 \mathrm{Ha}$ which was developed independently in the ecotourism sector. The attractions available at these locations were campsites lines, motor cross, ATV motorbikes, fun races adventure, hanging bicycle, photo spots selfie/wefie, notes, bicycles, and traditional villages. Within approximately one year, the local community was able to develop ecotourism by building asphalt roads without heavy equipment (ethics of forest conservation), providing four toilet points, two small mosques, and three unique cars to shuttle visitors.

Ecotourism development carried out by local communities who are members of the LMDH Wana Cendana strongly prioritized local knowledge, local culture, community welfare and forest conservation. The local community was able to change the hill called "Gunung Dago", a former mine into beautiful tourist attractions. Even though they collaborated with Perhutani KPHBogor, they did not depend on instructions and capital support. Such conditions indicated that the empowerment of local communities in Dago Village is bottom-up and did not neglect forest preservation.

The determination of ecotourism as a medium of cooperation with Perhutani was a decision of the local community that relies on local knowledge and culture. They were very aware that the condition of Mount Dago is not suitable as agricultural land. This is caused by soil conditions that are very thin and dominated by rocks, making it very difficult to grow crops. The local community only prioritized deliberation, cooperation and togetherness to realize ecotourism in the region. They were willing to do cooperation to open a road on Mount Dago, which took about eight months.

One aspect that signifies that the development of ecotourism prioritizes welfare was the sharing system between local communities and Perhutani. The profitsharing system was determined based on the proportion of the contribution of each party. The agreement resulted $70 \%$ for local community and Perhutani KPH Bogor gets $30 \%$ of revenue after operating costs were deducted. Conditions in this context indicate that the local community has a substantial contribution to the development of ecotourism and can open new jobs for 12 officers and six traders.

\section{Knowledge, Culture and Local Resources in the Development of Mount Dago Ecotourism}

Referring to information from all informants (members and non-members), it can be interpreted that LMDH Wana Cendana recognized the problems that exist in Mount Dago without instructions from Perhutani. This stage is one of the essential stages in empowering local communities. The problems faced by LMDH were the forerunners of the development of local community-based ecotourism.

The next process after the local community recognized the problem was reading the potential and determining the direction of empowerment based on the local community. The local community though that the motor cross enthusiasts from various regions was one of the things that makes them realize that Mount Dago has good natural potential. Besides, the members argued that Mount Dago had long been used as a gathering place for people who came 
from various regions. This indicated that Mount Dago had the potential for tourist attractions because the view is excellent.

The explanation above was based on the explanation from the chairman and several members summarized in the interview excerpt below:

\begin{abstract}
"Because in Dago, for palawija (cassava-based food) plants are not good, less developed because there are much stones. To restore it take a long time, so I think maybe this is better if it is managed for ecotourism because ecotourism does not leave the rules of preservation of nature. Mount Dago is also often used as a hangout place, for both youth and motor cross enthusiasts. "
\end{abstract}

Ecotourism development carried out in the Village of Dago prioritized local resources, so that it relies on all the potential possessed by all members of the institution. The implementation of ecotourism based on the local community was very suitable with the empowerment model that starts from the bottom or bottom-up. This conformity can be seen from the independence of the local community during the development of ecotourism, both from planning, implementation, decision making and evaluation that minimize dependence on external parties.

The development of Gunung Dago ecotourism is a form of collaboration between local communities who are members of the LMDH Wana Cendana and Perhutani KPH Bogor. The collaboration between the two parties aims to improve the welfare of local communities and improve forest sustainability. The fact that occurred in Dago Village shows the difference in the proportion of contributions between local communities and Perhutani. The local community has a role and a substantial proportion of contributions in various aspects of ecotourism development, ranging from planning, decision making, capital collection and evaluation that they do independently. Activities that are driven by cultural aspects and the independence of the local community can be proven by a summary of the results of the interview, both from key informants and supporters:

"All activities here are indeed started with
cooperation. Making the road from here
to the top is purely cooperation without
instructions and assistance from Perhutani.
The capital has initially been mutual
cooperation. So, in the first three months,
we are pure cooperation. Move rocks, bright
bushes and everything. We will just walk
eight months to the top."

"The first must be friendly. Dress modestly and cannot complain. The main thing is we have to be polite with guests."

"We as part of a religious community and the majority of Islam, we provide the mosque, below and above."

Based on the above interview excerpt, it can be interpreted that the members who are members of the local community prioritize the values of cooperation, togetherness and kinship. They realized the values of cooperation in making the road from the bottom to the top of the hill. This is the first step they have taken to simplify the process of developing infrastructure and facilities (tourism objects) next.

In this context, the local community of Dago Village realizes that local culture can be used as a capital for community empowerment. In addition, the local culture that is also significantly owned affects the products of the empowerment, such as the design of the gazebo, archway and lodging that resembles the design of Sundanese and Banten traditional houses. In addition, the culture of the local religious community (the majority of Muslims) is realized by the 
availability of places of worship in the form of two prayer rooms. Provision of places of worship is intended to facilitate members and visitors to perform worship. The local community as the manager also prioritizes forest conservation, so that the construction of the rides and facilities mentioned above do not use permanent materials at all.

In addition to cooperation capital and the natural potential of Mount Dago, the local community also succeeded in utilizing the local cultural heritage for the implementation of ecotourism development. The cultural heritage is the hospitality and courtesy of the Dago community. They assume that visitors are guests who must be served in a friendly and polite manner. On the other hand, they, as residents of Dago Village who are charismatic and friendly, also prioritize hard work and are not easy to complain.

Jim Ife explained that in the local community - based empowerment process, there was a huge problem, namely in the form of funding. In general, empowerment is very dependent on funding from certain countries or institutions (Ife \& Tesoriero, 2008: 254). If related to the case of Mount Dago, the development of ecotourism is one step ahead of the empowerment scheme in general. This can be proven by the strength of the local community in overcoming the problem of funding independently. Thus, it can be interpreted that LMDH Wana Cendana has been able to utilize local resources owned for the development of ecotourism.

The involvement of human resources (local) in the development of ecotourism indicates the opening of space for learning and broad opportunities to increase the capacity of independence. Members of the local community have no experience in the field of ecotourism and forestry, but the existence of ecotourism makes them better understand how to manage ecotourism to improve the welfare of members without destroying forests. The characteristics of a friendly and open local community are a supporting force in the development of ecotourism. Their openness is reflected in their willingness to accept criticism and suggestions from visitors.

The above description shows the compatibility between the conditions of ecotourism development based on the empowerment of local communities in Dago Village with a combination of concepts developed in the previous chapter. The combination comes from one crucial element in the concept of ecotourism and the empowerment of local communities, namely local knowledge and culture that are used together in the process of developing ecotourism. All members of the local community who are members of the LMDH Wana Cendana successfully involve themselves actively without an intensive process of mentoring from external parties, so they rely on local knowledge and culture in recognizing the problems encountered, planning steps to handle, identifying potentials owned and implementing ecotourism development.

The success of the Dago Village local community in relying on local knowledge and culture for the development of ecotourism is very much in line with the main requirements for empowering local communities in the field of ecotourism. The criteria of the local community, in that case, are very consistent with Jim Ife's concept, which states that change from below is the main idea of empowerment at the local community level. Changes from below are directed to the ecotourism sector by the local communities involved in it. The empowerment process at the local community level in Dago Village was not preceded by an external mentoring process, but the local community involved in the empowerment process highly valued local knowledge and culture. Thus, it can be interpreted that the local community, in this 
case, managed to utilize local knowledge and culture independently to initiate the process of empowering local communities as well as ecotourism.

If it was analyzed in-depth, then the local community in this context has succeeded in integrating local knowledge and culture to recognize the problems faced, planning problem solving and implementing ecotourism development. This shows that the local knowledge and culture conceptualized by Jim Ife is largely very applicable in the case of developing local community-based ecotourism in Dago Village. The situation is illustrated through the independent use of local knowledge and culture in identifying various problems and determining the direction of use in the ecotourism sector.

Based on the description above, it can be interpreted that the findings of the development of ecotourism based on local community empowerment are in accordance with the concept building used in this study. The use of local culture by the local community of Dago Village in the ecotourism sector is very compatible with the local culture contained in the combination of the concepts of local community empowerment and ecotourism. The success of local communities in utilizing local culture as the capital as well as a product of empowerment and ecotourism is a meeting point of two different concepts, namely empowering local communities and ecotourism.

Conformity between the conditions of ecotourism development with the concept that is built can also be seen from the workings of local communities that purely rely on their culture. Jim Ife asserted that in the sphere of respecting local culture for the empowerment it still needed a process of assistance from external parties. However, local community-based empowerment in the Gunung Dago ecotourism sector does not at all signify an intensive process of mentoring from external parties (Perhutani $\mathrm{KPH}$ Bogor). This condition shows that the local community of Dago Village is more independent from empowerment at the level of the local community that Jim Ife works on.

If it is related to local culture in the context of ecotourism, then the emphasis is on the openness of the local community to present their culture in ecotourism activities. The local community of Dago Village as an ecotourism manager has been able to utilize local culture as the capital as well as products that can be realized and enjoyed by visitors. The review explained above shows that the local community has the freedom to plan and implement ecotourism development in the village. The freedom of the local community can be seen in their freedom to express their culture in the development of Mount Dago ecotourism.

\section{Dago Forest Conservation Efforts}

The concept of local empowerment and ecotourism much prioritizes the participation of local resources in the process. One meeting point between the two concepts is the participation of local resources in the implementation of forest conservation. In this context, local communities who are members of the LMDH Wana Cendana actively involve themselves in the development of ecotourism that promotes the conservation of the Dago forest. The results of this study outline indicate that local resources prioritize efforts that integrate empowerment and conservation.

All the contribution of local resources related to the development of ecotourism that prioritizes forest conservation does not stand alone, but local resources in this context are strongly supported by the knowledge and culture of the local community. The development of Gunung Dago ecotourism is primarily based on local resources that 
are integrated with local knowledge and culture. These three integrated things are put to good use by local communities to enforce forest conservation efforts as a form of their responsibility.

The implementation of forest conservation in Mount Dago is a form of independence from the local community. Although they have absolutely no experience and expertise in the field of ecotourism that prioritizes conservation, they are trying to implement conservation in accordance with the knowledge and skills they have. In addition, the use of local skills and knowledge in the context of strengthening forest functions is strongly supported by local culture in the form of cooperation and deliberation that they rely on in the development of ecotourism.

Observation results indicate that the local community that is incorporated in $\mathrm{LMDH}$ Wana Cendana is very compliant with the cooperation rules agreed upon by Perhutani $\mathrm{KPH}$ Bogor. In addition to changing the arid Mount Dago into beautiful, they also realize compliance with efforts to develop ecotourism that puts forward the principles of conservation, so as not to use heavy equipment in production forests that are used as environmental services (ecotourism).

Forest conservation efforts undertaken by local communities can also be proven with a summary of the results of interviews, both with key informants and supporting informants:

"At first I wanted to start in 2012, but the infrastructure here is not right, the hill is still barren and rocks, so we wait until the green returns. "

"First, planting trees, development does not damage the environment. Even if there is land clearing, it must be green again. "
"We are trying two types, protective plants and fruits. Produce too. if below is OK, there is Jabon; white teak has been seven years. "

The above interview excerpts indicate that local communities are faced with problems that complicate conservation efforts. They argue that the condition of Mount Dago, which is a former mine is one of the challenges they have to face. In this context, local communities make use of the knowledge and skills they have so that they can plant trees on the land that has a thin layer of soil and is dominated by rocks by mutual assistance which takes a long time. The local community has been planning the ecotourism of Mount Dago since 2012, but the condition of the location is still bare and arid, so they try to plant trees and wait for Mount Dago to return for approximately six years.

Based on the explanation above, it can be interpreted that local communities have a high concern for forest sustainability. This they proved by the strength of local resources that were able to plan and implement forest conservation long before the Mount Dago ecotourism was formed. If it is related to the concept of empowering local communities and ecotourism, it can be said that the local community has applied the basic principles of empowerment and ecotourism in the form of planning and implementing conservation that is carried out independently without waiting for instructions from Perhutani. So, it can be simplified that the condition of the Dago Village local community is very compatible with the empowerment mechanism with a bottom-up scheme realized in the ecotourism sector.

The form of responsibility and independence of the local community can be illustrated through the following summary of interviews: 
"We replant. We have already cut down, unproductive and less useful trees we cut. We have planted more than 1000 trees. For example, before it was bald, now it is lush. Fruits too much. There are jackfruit, petai, mango."

"Some of them bought, some got help from IPB. Incidentally, there is indeed a program; we are asking for help from the tree."

The form of independence of local resources in the context of Dago forest conservation is reflected in the greening strategy in accordance with its potential. The informants involved in the activity explained that they not only relied on tree seedlings from Perhutani but were also actively looking for ways to carry out forest conservation independently. The LMDH Wana Cendana members believe that they got information regarding tree seed assistance provided by IPB (Bogor Agricultural University), so the local community compiled a letter of submission to utilize the assistance. Thus, the local community received as much as 700 tree seedlings.

In the early stages of ecotourism planning, the local community had cut down unproductive trees to open roads in the Mount Dago area. They followed up the process by replanting 1000 trees. The local community carried out reforestation in cooperation and cared for the trees they planted so that now Mount Dago is a lush and clean tourist location.

The seriousness of the local community in forest conservation efforts is also manifested by the provision of water and trash bins to maintain cleanliness. In addition, the availability of water can be utilized by members who work in the ecotourism area to water the plants and trees that they plant during the dry season. If it is related to the concepts of empowerment and ecotourism, then these efforts can be interpreted as a form of balance between improving the welfare of local communities and forest preservation.

The background of local communities who have no insight into forest conservation is a challenge in the development of Gunung Dago ecotourism. However, the local community succeeded in providing answers to these challenges by restoring the function of forests that had long been damaged by mining activities. Members of the local community involved in the development of ecotourism only understand the fundamental issues related to forest conservation, such as replanting trees, keeping the forest clean and caring for the trees they have planted as much as possible.

If related to essential elements contained in the concept of empowering local communities and ecotourism, it can be concluded that the local community of Dago Village has succeeded in integrating local resources supported by local knowledge and culture to carry out ecotourism development. Local knowledge that is relied on to improve forest conservation is very limited to geographical conditions and fundamental issues related to conservation efforts, so there is no local knowledge and culture that leads explicitly to forest conservation efforts.

The explanation above indicates that although the local community of Dago Village has embarked on conservation efforts, it is very much in need of a mentoring process to increase knowledge and skills related to forest conservation. The assistance process is essential to maintain a balance between forest use in the ecotourism sector and forest conservation and increase the capacity of local communities in the forest conservation sector. In addition, the local community that is incorporated in LMDH Wana Cendana is a party that is in direct contact with the forest as well as a party responsible for forest conservation, so it is vital to be equipped with knowledge and insight about forest conservation. 


\section{Conclusion}

The development of Gunung Dago ecotourism carried out by local communities who are members of the LMDH Wana Cendana, in general, is in accordance with the concept of empowering local communities and ecotourism. The local community empowerment scheme proposed by Jim Ife begins with assistance and capital. If it is related to the Mount Dago case, then the development of ecotourism is one step ahead of the Jim Ife empowerment scheme. The local community considers that the toughest challenge in developing ecotourism is in terms of capital, but they remain optimistic about the sustainability of the ecotourism. In this context, the local community positions itself as a community business group that seeks to improve welfare independently by relying on local knowledge, culture and resources without waiting for government programs.

If it was related to previous studies, the results of this study can be used as a rich complement to findings that indicate the involvement of local communities in the implementation of empowerment (planning, implementation and evaluation). The results of this study can also be used as an example of empowering local communities in the ecotourism sector which not only prioritizes economic aspects but also prioritizes the learning process of local communities by utilizing all its potential.

This research needs to be developed with action research that is able to assist the development of local communitybased ecotourism in Dago Village and other locations that have similar cases. The application of action research in the development of ecotourism is expected to be able to integrate local communities who are members of the LMDH Wana Cendana with external parties who can support the development of ecotourism in these locations.

\section{Declaration of Ownership}

This article is our original work.

\section{Conflict of Interest}

There is no conflict of interest to declare in this article.

\section{Ethical Clearance}

This study was approved by the institution.

\section{References}

Ahmad, M. S., \& Abu Talib, N. B. (2016). Analysis of community empowerment on projects sustainability: Moderating role of sense of community. Social Indicators Research, 129(3), 1039-1056. https://doi. org/10.1007/s11205-014-0781-9

Amalu, T. E., Otop, O. O., Duluora, E. I., Omeje, V. U., \& Emeana, S. K. (2018). Socio-economic impacts of ecotourism attractions in Enugu state, Nigeria. GeoJournal, 83(6), 1257-1269. https://doi. org/10.1007/s10708-017-9830-7

Brown, S., \& Zarin, D. (2013). What does zero deforestation mean? Science, 342(6160), 805-807. science. 1241277

Ellis, E. A., Romero Montero, J. A., \& Hernández Gómez, I. U. (2017). Deforestation processes in the state of quintana roo, mexico: The role of land use and community forestry. Tropical Conservation Science, 10. https://doi. org/10.1177/1940082917697259

Hegde, N., Elias, M., Lamers, H. A. H., \& Hegde, M. (2017). Engaging local communities in social learning for inclusive management of native fruit trees in the Central Western Ghats, India. Forests Trees and Livelihoods, 26(1), 65-83. https://doi.org/10.1080/14728028.2016.12 57398 
Ife, J., \& Tesoriero, F. (2008). Community development: Alternatif pengembangan masyarakat di era globalisasi (1st ed.). Pustaka Pelajar.

Kelly, E. C. (2018). The role of the local community on federal lands: The Weaverville community forest. Humboldt Journal of Social Relations, 40(40), 163-177. https://doi.org/10.1017/ CBO9781107415324.004

Lawson, L., \& Kearns, A. (2014). Rethinking the purpose of community empowerment in neighbourhood regeneration: The need for policy clarity. Local Economy, 29(1-2), 65-81. https://doi. org/10.1177/0269094213519307

Mukhtar. (2013). Metode praktis dan penelitian deskriptif kualitatif (1 ed.). Referensi (GP Press Group).

Perhutani. (2019). Pengelolaan hutan bersama masyarakat (PHBM). http:// bumn.go.id/perhutani/halaman/159. Accessed in 4 March 2019.

Ridwan, Junus, M., Mahbub, M. A. S., \& Windarti, R. P. (2018). Kinerja kelompok tani dalam pengelolaan hutan tanaman rakyat di Desa Bacu-Bacu Kabupaten Barru. Jurnal Hutan dan Masyarakat, 10(2), 231. https://doi.org/10.24259/jhm. v10i2.4108

Sardjo, S., Darmajanti, L., \& Boediono, K. C. (2017). Implementasi model evaluasi formatif program pembangunan sosial (EFPPS): Partisipasi multipihak dalam evaluasi program (1 ed.). FISIP UI dan Yayasan Pustaka Obor Indonesia.
Schelhas, J., Hitchner, S., Johnson Gaither, C., Fraser, R., Jennings, V., \& Diop, A. (2016). Engaging African American landowners in sustainable forest management. Journal of Forestry, 115(1), 26-33. https:// doi.org/10.5849/jof.15-116

Stronza, A. L., Hunt, C. A., \& Fitzgerald, L. A. (2019). Ecotourism for conservation? AnnualReviewofEnvironmentandResources, 44(1), 229-253. https://doi.org/10.1146/ annurev-environ-101718-033046

Timko, J., Green, S., Sharples, R., \& Grinde, A. (2015). Using a community-driven approach to identify local forest and climate change priorities in Teslin, Yukon. Cogent Social Sciences, 1(1), 1-12. https://doi.org/10.1080/23311886.2015.10 47564

Uzama, A., \& Walter, P. (2018). Incorporating ecotourism into social education (shakai kyouiku 社会教育) and lifelong learning (shougai gakushuu 生涯学習) in Japan. Journal of Adult and Continuing Education, 24(1), 18-36. https://doi. org/10.1177/1477971417753975

Yin, R. K. (2008). Studi kasus desain dan metode (1 ed.). PT. Rajagrafindo Persada.

Zanamwe, C., Gandiwa, E., Muboko, N., Kupika, O. L., \& Mukamuri, B. B. (2018). Ecotourism and wildlife conservationrelated enterprise development by local communities within Southern Africa: Perspectives from the Greater Limpopo Transfrontier Conservation, SouthEastern Lowveld, Zimbabwe. Cogent Environmental Science, 4(1), 1-13. https:// doi.org/10.1080/23311843.2018.1531463 